\title{
Bacillus acidiproducens sp. nov., vineyard soil isolates that produce lactic acid
}

Correspondence

Young-Hyo Chang

yhchang@kribb.re.kr

\section{Min Young Jung, ${ }^{1}$ Joong-Su Kim ${ }^{2}$ and Young-Hyo Chang ${ }^{1}$}

\begin{abstract}
${ }^{1}$ Korean Collection for Type Cultures, Biological Resource Center, Korea Research Institute of Bioscience and Biotechnology, 52 Oeundong, Daejeon 305-806, Republic of Korea

${ }^{2}$ Jeonbuk Branch Institute, Molecular Bioprocess Research Center, Korea Research Institute of Bioscience and Biotechnology, 1404 Sinjeong-dong, Jeongeup-si, Jeonbuk 580-185, Republic of Korea
\end{abstract}

\begin{abstract}
Two novel spore-forming lactic acid bacteria, strains SL213 ${ }^{\top}$ and SL1213, were isolated from vineyard soils in Korea. Cells of both isolates were rod-shaped bacilli and contained subterminal, ellipsoidal spores. Strains were facultatively anaerobic, catalase-positive, oxidase-negative and motile with single flagella. meso-Diaminopimelic acid, glucose and galactose were detected in whole-cell hydrolysates. Major fatty acids found in the strains were anteiso- $C_{15: 0}$, iso- $C_{15: 0}$, iso$\mathrm{C}_{16: 0}, \mathrm{C}_{16: 0}$ and anteiso- $\mathrm{C}_{17: 0}$. The $\mathrm{G}+\mathrm{C}$ contents of the DNA were 46.1 and $46.3 \mathrm{~mol} \% .16 \mathrm{~S}$ rRNA gene sequences from the two strains were almost identical (99.9\%) and placed them in the genus Bacillus, according to phylogenetic analysis. The type strains most closely related to SL213 ${ }^{\top}$ were Bacillus coagulans ATCC $7050^{\top}$ and Bacillus badius ATCC $14574^{\top}$, with $16 \mathrm{~S}$ rRNA gene sequence similarities of 96.9 and $95.9 \%$, respectively. Levels of DNA-DNA relatedness between strain SL213 ${ }^{\top}$ and strain SL1213, B. coagulans ATCC $7050^{\top}$ and B. badius ATCC $14574^{\top}$ were $92.5,49.0$ and $27.5 \%$, respectively. On the basis of $16 \mathrm{~S}$ rRNA gene sequences and chemotaxonomic and phenotypic evidence given in this study, we report that SL213 ${ }^{\top}$ represents a novel species, for which the name Bacillus acidiproducens sp. nov. is proposed. The type strain is $\mathrm{SL}_{213^{\top}}\left(=\right.$ KCTC $\left.13078^{\top}=\mathrm{JCM} 14638^{\top}\right)$.
\end{abstract}

The members of the genus Bacillus Cohn 1872 are Grampositive, rod-shaped, aerobic or facultatively anaerobic, spore-forming bacteria. Within the bacilli, a spore-forming lactic acid bacillus was first described in 1932 and it was originally known as 'Lactobacillus sporogenes' (HorowitzWlassowa \& Nowotelnow, 1932). Results from further physiological and biochemical characterization caused the strain to be transferred into the Bacillus coagulans group, a change in classification that was later confirmed by genotypic studies (Becker \& Pederson, 1950; De Clerck et al., 2004). More recently, other spore-forming rods that produce lactic acid have been grouped into the genus Bacillus (Gibson \& Gordon, 1974).

A unique characteristic of lactic acid-producing strains of the genus Bacillus is their ability to produce spores and lactic acid; the spores can stay dormant for extended periods under stressful environmental conditions, including high temperature and acidic $\mathrm{pH}$. Organisms from the genus Bacillus have been isolated frequently and from almost every environment, such as marine areas (Bae et al., 2005; Gugliandolo et al., 2003; Yoon et al., 2003), airborne

The GenBank/EMBL/DDBJ accession numbers for the $16 \mathrm{~S}$ rRNA gene sequences of strains SL213 ${ }^{\top}$ and SL1213 are EF379274 and EF392690. dust (Shivaji et al., 2006) and soil (Albert et al., 2005; Gatson et al., 2006; Heyrman et al., 2005; Logan et al., 2002; Palmisano et al., 2001). In contrast, isolation of spore-forming, lactic acid-producing Bacillus strains has been reported only rarely, from products of milk (Hammer, 1915), fermented foods, plants (Alkan et al., 2007), sewage sludge (Kotay \& Das, 2007) and soil (Patel et al., 2006). In this study, we report the isolation and characterization of novel bacteria from vineyard soil in Korea that form spores, produce lactic acid, are facultatively anaerobic and grow at temperatures up to $55{ }^{\circ} \mathrm{C}$. After polyphasic characterization, the isolates were classified in a single novel species of the genus Bacillus.

Isolation of spore-forming lactic acid bacteria was performed according to the method described by Yanagida et al. (1997). One gram of a soil sample was mixed with $9 \mathrm{ml} 0.75 \% \mathrm{NaCl}$ solution. The mixed solution was heated for $30 \mathrm{~min}$ at $60{ }^{\circ} \mathrm{C}$, after which one drop of the suspension was spread onto GYP agar containing $1 \%$ $\mathrm{CaCO}_{3}$ (Yanagida et al., 1997). The culture was incubated under anaerobic conditions with a gas phase of $\mathrm{H}_{2} / \mathrm{CO}_{2} / \mathrm{N}_{2}$ $\left(7: 5: 88\right.$, by vol.), in a Forma anaerobic chamber, at $30{ }^{\circ} \mathrm{C}$ for 2-3 days. After incubation, acid-producing bacteria were identified by the appearance of clear zones around 
colonies, and were then selected and purified by repeated isolation. Two novel spore-forming, lactic acid bacteria, designated SL213 ${ }^{\mathrm{T}}$ and SL1213, were maintained on tryptic soy agar (TSA, Difco) at $30{ }^{\circ} \mathrm{C}$. Subsequent analysis was performed to determine $16 \mathrm{~S}$ rRNA gene sequences, phenotypic characteristics and DNA-DNA relatedness to type strains of related species based on 16S rRNA gene sequence similarity.

Cells grown on TSA were used to determine physiological characteristics of the isolates. Gram staining was performed using a Gram stain set (Difco). Cell morphology and size were examined using phase-contrast microscopy (Nikon 80i). For determination of flagellum type, cells were negatively stained with $1 \%(\mathrm{w} / \mathrm{v})$ uranyl acetate according to the method described by Chang et al. (2002) and observed with a model CM-20 transmission electron microscope (Philips). Some physiological characteristics were determined using API $20 \mathrm{E}$ and API $50 \mathrm{CH}$ galleries (bioMérieux) according to the instructions of the manufacturer. Catalase activity was detected by placing drops of $3 \%(\mathrm{v} / \mathrm{v}) \mathrm{H}_{2} \mathrm{O}_{2}$ on cultures growing on GYP and observing oxygen bubbles. Oxidase activity was determined using an Oxy-swab (bioMérieux). Production of lactic acid was confirmed using a D-lactic acid/L-lactic acid kit (Rbiopharm; Roche Diagnostics). The $\mathrm{pH}$ range for growth was checked using $500 \mathrm{ml}$ flasks containing $250 \mathrm{ml}$ tryptic soy broth (TSB) with a pH of 4-8 (in $0.5 \mathrm{pH}$ unit increments) at $37{ }^{\circ} \mathrm{C}$. TSB containing $100 \mathrm{mM} \mathrm{Na}_{2} \mathrm{HPO}_{4} /$ $\mathrm{NaH}_{2} \mathrm{PO}_{4}$ was used as buffer. Growth was checked by monitoring optical density at $595 \mathrm{~nm}$ (Bio-Rad). To determine the optimum growth temperature and tolerance of $\mathrm{NaCl}$, cells were cultured in TSB for 2 days at temperatures ranging from 15 to $60{ }^{\circ} \mathrm{C}$ and in $\mathrm{NaCl}$ concentrations up to $7 \%(\mathrm{w} / \mathrm{v})$. Motility was observed in TSB solidified with $0.4 \%$ agar.

Purified cell-wall preparations were obtained as described by Schleifer \& Kandler (1972). Amino acid and sugar analyses of the whole-cell hydrolysate were performed as described by Staneck \& Roberts (1974), using TLC on cellulose plates (Merck) with the solvent system of Rhuland et al. (1955).

Cells of strains SL213 ${ }^{\mathrm{T}}$ and SL1213 stained Gram-positive and were facultatively anaerobic rods that contained subterminal ellipsoidal spores. Single cells were observed as slightly curved rods, $4.0-4.5 \mu \mathrm{m}$ long and $0.8-1.2 \mu \mathrm{m}$ in diameter. Isolates were motile with single flagella and produced lactic acid and grew in TSB containing $5 \% \mathrm{NaCl}$. Strains were negative for oxidase, indole production and nitrate reduction, but positive for catalase and acid production from ribose, mannitol and sucrose. Isolates were more similar to Bacillus coagulans ATCC $7050^{\mathrm{T}}$ than to Bacillus badius ATCC $14574^{\mathrm{T}}$ in their physiological properties (De Clerck et al., 2004). These results are summarized in the species description and in Table 1.

In the analysis of whole-cell hydrolysates, meso-diaminopimelic acid and glucose and galactose were detected in the isolates. The predominant cell-wall amino acid and sugars found in the isolates agreed with results for the type strain of B. coagulans (De Clerck et al., 2004).

The isolates and several Bacillus reference strains were subjected to cellular fatty acid methyl ester analysis to confirm the genus classification. All the tested strains were grown on TSA ( $\mathrm{pH} 7.0)$ for $24 \mathrm{~h}$ at $37{ }^{\circ} \mathrm{C}$. Fatty acids were extracted and analysed according to the standard protocol of the Microbial Identification System (MIDI Microbial ID). Extracts were analysed using a gas chromatograph (model 6890N and autosampler 7683; Agilent) and identified using the Microbial Identification Sherlock software package.

The cellular fatty acid profiles of the strains are presented in Table 2. The predominant fatty acids of the two novel isolates and B. coagulans ATCC $7050^{\mathrm{T}}$ were anteiso- $\mathrm{C}_{15: 0}$, anteiso- $\mathrm{C}_{17: 0}$, iso- $\mathrm{C}_{16: 0}$, iso- $\mathrm{C}_{15: 0}$ and $\mathrm{C}_{16: 0}$, comprising approximately $95 \%$ of the fatty acids extracted. The major fatty acids of the isolates were similar to those reported for B. coagulans ATCC $7050^{\mathrm{T}}$ in previous studies (De Clerck et al., 2004). Among the analysed reference strains, B. badius ATCC $14574^{\mathrm{T}}$ differed significantly from the novel isolates in that the only predominant fatty acid was iso- $\mathrm{C}_{15: 0}$ $(51.43 \%)$ and the minor components were present in smaller amounts. The cellular fatty acid profiles indicate that strains SL213 ${ }^{\mathrm{T}}$ and SL1213 were more similar to $B$. coagulans ATCC $7050^{\mathrm{T}}$ than to B. badius ATCC $14574^{\mathrm{T}}$ in some major groups, although cellular fatty acids alone do not give good differentiation within the bacilli.

Nearly complete 16S rRNA gene sequences for strains SL $213^{\mathrm{T}}$ and SL1213 were determined according to Chang et al. (2001). The sequences were aligned manually with representatives of the genus Bacillus and related taxa using known 16S rRNA secondary structure information. Phylogenetic trees were inferred by using the neighbourjoining (Saitou \& Nei, 1987), Fitch-Margoliash (Fitch \& Margoliash, 1967) and maximum-parsimony (Fitch, 1971) methods. Evolutionary distance matrices for the neighbour-joining and Fitch-Margoliash methods were generated according to the model of Jukes \& Cantor (1969). The PHYLIP package (Felsenstein, 1993) was used for all analyses. The resultant tree topology was evaluated by bootstrap analyses (Felsenstein, 1985) of the neighbour-joining tree based on 1000 resamplings.

A preliminary comparison of the nucleotide sequences with sequences in GenBank indicated that the isolates were closely related to members of the genus Bacillus. A rooted phylogenetic tree showing the relationship between strains SL213 ${ }^{T}$ and SL1213 and representatives of the genus Bacillus is shown in Fig. 1. The strains formed a highly significant monophyletic clade with $B$. coagulans ATCC $7050^{\mathrm{T}}$ and $B$. badius ATCC $14574^{\mathrm{T}}$. The clade was also confirmed in other treeing algorithms, supported by a highly significant bootstrap value of $100 \%$ (not shown). On the basis of pairwise 16S rRNA gene sequence similarities, the closest phylogenetic relative of strain 
Table 1. Differential physiological characteristics of strains $S L 213^{\top}$ and $S L 1213$ and closely related type strains

Strains: 1, strains SL213 ${ }^{\mathrm{T}}$ and SL1213; 2, B. coagulans ATCC $7050^{\mathrm{T}}$; 3, B. badius ATCC $14574^{\mathrm{T}}$. +, Positive; -, negative; w, weakly positive. All strains are motile, positive for catalase and negative for oxidase, reduction of nitrate and nitrite, hydrolysis of casein, DNA and Tween 80, formation of $\mathrm{H}_{2} \mathrm{~S}$ and indole and activities of phosphatase, urease, phenylalanine deaminase and ornithine and lysine decarboxylases. Data were obtained in this study.

\begin{tabular}{|c|c|c|c|}
\hline Characteristic & 1 & 2 & 3 \\
\hline Cell length $(\mu \mathrm{m})$ & $4.0-4.5$ & $5.5-6.0$ & 5.0 \\
\hline \multicolumn{4}{|l|}{ Temperature for growth $\left({ }^{\circ} \mathrm{C}\right)$} \\
\hline Range & $25-55$ & $30-55$ & $15-50$ \\
\hline Optimum & 37 & 37 & 30 \\
\hline Colony colour & White or ivory & White & Cream-white \\
\hline Spore shape & Ellipsoidal & Ellipsoidal & Round \\
\hline Spore location & (Sub)terminal & (Sub)terminal & Central \\
\hline Anaerobic growth & + & + & - \\
\hline \multicolumn{4}{|l|}{ Growth in $\mathrm{NaCl}$ at: } \\
\hline $5 \%$ & + & + & - \\
\hline $7 \%$ & - & + & - \\
\hline Lactic acid production & + & + & - \\
\hline Hydrolysis of gelatin & - & - & + \\
\hline Acetoin production (Voges-Proskauer test) & + & + & - \\
\hline$\beta$-Galactosidase (ONPG) & - & + & - \\
\hline Methyl red test & - & + & - \\
\hline \multicolumn{4}{|l|}{ Acid production from: } \\
\hline Glycerol & + & + & - \\
\hline L-Arabinose & + & - & - \\
\hline Ribose & + & - & - \\
\hline D-Xylose & + & - & - \\
\hline Galactose & + & + & - \\
\hline Glucose & + & + & - \\
\hline Fructose & + & + & - \\
\hline Mannose & + & + & - \\
\hline Rhamnose & + & - & - \\
\hline Mannitol & + & - & - \\
\hline Methyl $\alpha$-D-glucoside & + & - & - \\
\hline$N$-Acetylglucosamine & + & + & - \\
\hline Aesculin & - & + & - \\
\hline Salicin & - & $\mathrm{w}$ & - \\
\hline Lactose & - & + & - \\
\hline Sucrose & + & - & - \\
\hline Trehalose & - & + & - \\
\hline Starch & - & $\mathrm{w}$ & - \\
\hline Turanose & - & + & - \\
\hline D-Lyxose & + & - & - \\
\hline D-Tagatose & + & - & - \\
\hline Gluconate & + & + & - \\
\hline
\end{tabular}

SL213 ${ }^{\mathrm{T}}$ was B. coagulans ATCC $7050^{\mathrm{T}}(96.9 \%)$, followed by $B$. badius ATCC $14574^{\mathrm{T}}(95.9 \%$ similarity $)$. The sequences of SL213 ${ }^{\mathrm{T}}$ and SL1213 showed high similarity (99.9\%), suggesting that the two strains belong to the same species. It was evident from $16 \mathrm{~S}$ rRNA gene sequence analysis that the isolates represented a novel genomic species in the genus Bacillus, as no strains of species with validly published names showed more than $97 \% 16 \mathrm{~S}$ rRNA gene sequence similarity (Stackebrandt \& Goebel, 1994). The 16S rRNA gene sequences for strains SL213 ${ }^{\mathrm{T}}$ (1379 nt) and SL1213 (1378 nt) were thus clearly discriminated from those of type strains of species of Bacillus.

For the determination of DNA $\mathrm{G}+\mathrm{C}(\mathrm{mol} \%)$ content, DNA was prepared according to Chang et al. (2002) and analysed by reversed-phase HPLC as described by Tamaoka \& Komagata (1984). The relative G+C contents were calculated by using standard DNA from Escherichia coli KCTC $2441^{\mathrm{T}}$. The DNA G+C contents of strain SL213 ${ }^{\mathrm{T}}$ and SL1213 were respectively 46.3 and $46.1 \mathrm{~mol} \%$. These 
Table 2. Cellular fatty acid composition of strains $S L 213^{\top}$ and SL1213 and closely related type strains

Strains: $1, \mathrm{SL}_{213^{\mathrm{T}}} ; 2$, SL1213; 3, B. coagulans ATCC $7050^{\mathrm{T}} ; 4$, B. badius ATCC $14574^{\mathrm{T}}$. Data were obtained in this study. All of the strains were grown on TSA ( $\mathrm{pH} 7.0$ ) for $24 \mathrm{~h}$ at $37^{\circ} \mathrm{C}$. Values are percentages of fatty acids; -, not detected.

\begin{tabular}{|c|c|c|c|c|}
\hline Fatty acid & 1 & 2 & 3 & 4 \\
\hline iso- $\mathrm{C}_{14: 0}$ & 1.57 & 2.06 & 1.53 & 1.46 \\
\hline $\mathrm{C}_{14: 0}$ & 1.46 & 2.39 & 1.57 & 1.82 \\
\hline iso- $\mathrm{C}_{15: 0}$ & 5.28 & 6.53 & 7.25 & 51.43 \\
\hline anteiso- $\mathrm{C}_{15: 0}$ & 53.39 & 48.21 & 49.01 & 5.85 \\
\hline $\mathrm{C}_{15: 0}$ & - & - & - & 1.32 \\
\hline $\mathrm{C}_{16: 1} \omega 7 c$ alcohol & - & - & - & 3.14 \\
\hline iso- $\mathrm{C}_{16: 0}$ & 7.06 & 9.24 & 8.98 & 5.44 \\
\hline $\mathrm{C}_{16: 1} \omega 11 c$ & - & - & - & 4.01 \\
\hline $\mathrm{C}_{16: 0}$ & 5.32 & 7.39 & 2.98 & 3.24 \\
\hline iso- $\mathrm{C}_{17: 1} \omega 10 c$ & - & - & - & 6.02 \\
\hline Summed feature ${ }^{\star}$ & - & - & - & 2.68 \\
\hline iso- $\mathrm{C}_{17: 0}$ & 1.04 & 1.23 & - & 3.52 \\
\hline anteiso- $\mathrm{C}_{17: 0}$ & 23.10 & 21.36 & 26.10 & 3.50 \\
\hline Unknown & 1.11 & 1.59 & 1.35 & 3.72 \\
\hline
\end{tabular}

${ }^{\star}$ Comprises iso- $\mathrm{C}_{17: 1} \mathrm{I}$ and/or anteiso- $\mathrm{C}_{17: 1} \mathrm{~B}$.

values are consistent with a taxonomic position of the strains within the genus Bacillus (Shida et al., 1997).

The novel strains and some Bacillus reference strains were subjected to genomic relatedness analysis. DNA-DNA hybridization was determined by the microplate hybridization method as described by Ezaki et al. (1989). Hybridization was carried out with photobiotin-labelled probes using a Flouroskan Ascent Fluorescent plate reader (Thermo Life Science) with three replications for each sample at $45{ }^{\circ} \mathrm{C}$. The mean genomic relatedness between the two isolates was $92.5 \%$, indicating that strains SL2 $13^{\mathrm{T}}$ and SL1213 represent a single species of Bacillus. The type strains of other Bacillus species were more distantly related to strain SL213 ${ }^{\mathrm{T}}$. The genomic relatedness between SL213 ${ }^{\mathrm{T}}$ and B. coagulans ATCC $7050^{\mathrm{T}}$ was $49 \%$ (96.9\% $16 \mathrm{~S}$ rRNA gene sequence similarity). Strain $\mathrm{SL} 213^{\mathrm{T}}$ and $B$. badius ATCC $14574^{\mathrm{T}}$ showed $27.5 \%$ genomic relatedness $(95.9 \%$ $16 \mathrm{~S}$ rRNA gene sequence similarity). These values were below the $70 \%$ threshold suggested for species delineation (Wayne et al., 1987), and indicate that strain SL213 ${ }^{\mathrm{T}}$ represents a novel species within the genus.

On the basis of the molecular and phenotypic evidence presented in this study, we propose that strains SL $213^{\mathrm{T}}$ and SL1213 be classified in a novel species of the genus Bacillus, Bacillus acidiproducens sp. nov.

\section{Description of Bacillus acidiproducens sp. nov.}

Bacillus acidiproducens (a.ci.di.pro.du'cens. N.L. n. acidum an acid; L. part. adj. producens producing; N.L. part. adj. acidiproducens acid-producing).

Cells are facultatively anaerobic, Gram-positive-staining rods $(0.8-1.2 \times 4.0-4.5 \mu \mathrm{m})$ that contain subterminal ellipsoidal spores. Motile by single polar flagella. Colonies grown on TSA are round, flat and white or ivory $5.0 \mathrm{~mm}$ in diameter). Grows at $25-55{ }^{\circ} \mathrm{C}$; optimum growth at $37{ }^{\circ} \mathrm{C}$. Grows at $\mathrm{pH}$ 6.0-7.5; optimum growth at $\mathrm{pH} 7.0$. Grows in $5 \% \mathrm{NaCl}$. Positive for catalase, acetoin and lactic acid production. Negative for oxidase, reduction of nitrate and nitrite, hydrolysis of gelatin, casein, DNA and Tween $80, \beta$-galactosidase (ONPG) and methyl red test, formation of $\mathrm{H}_{2} \mathrm{~S}$ and indole and activities of phosphatase, urease, phenylalanine deaminase and ornithine and lysine decarboxylases. Utilizes glycerol, L-arabinose, ribose, D-xylose, galactose, glucose, fructose, mannose, rhamnose, mannitol, methyl $\alpha$-D-glucoside, $N$-acetylglucosamine, sucrose, Dlyxose, D-tagatose and gluconate. The diagnostic amino

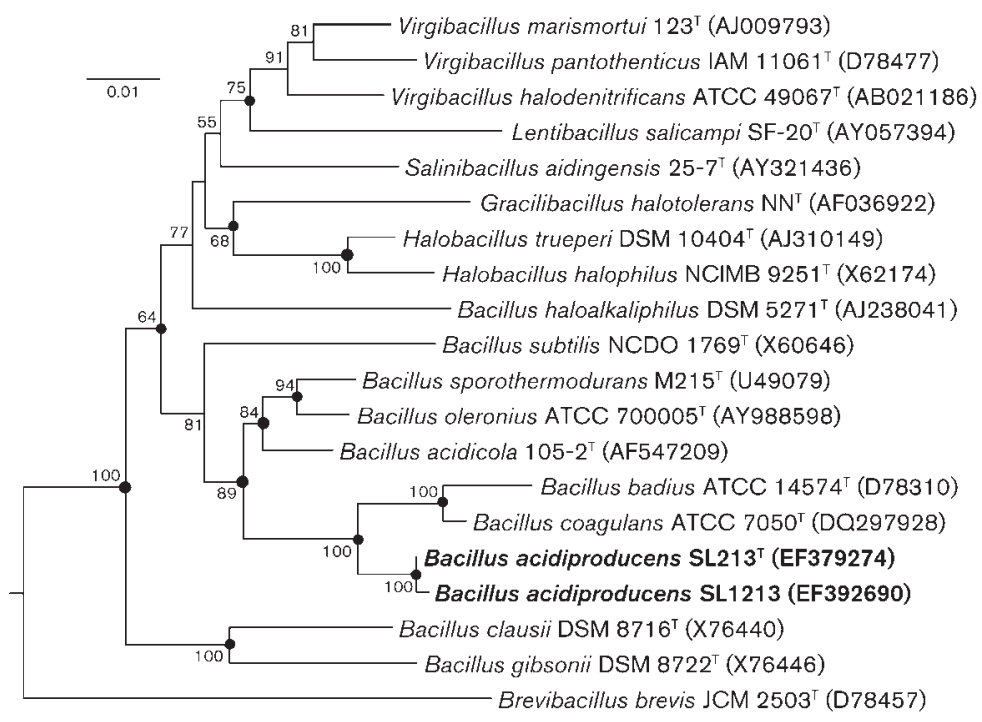

Fig. 1. Neighbour-joining phylogenetic tree, based on 16S rRNA gene sequences, showing the phylogenetic position of strains SL213 ${ }^{\top}$ and SL1213 and closely related taxa. Solid circles indicate that the corresponding nodes were also obtained in the maximum-parsimony tree. Bootstrap values from 1000 replications are shown as percentages at each node in the tree. Bar, 0.01 substitutions per nucleotide position. 
acid is meso-diaminopimelic acid and the major cell-wall sugars are glucose and galactose. Major fatty acids are anteiso- $\mathrm{C}_{15: 0}$, iso- $\mathrm{C}_{15: 0}$, iso- $\mathrm{C}_{16: 0}, \mathrm{C}_{16: 0}$ and anteiso$\mathrm{C}_{17: 0}$. The DNA $\mathrm{G}+\mathrm{C}$ content of the type strain is $46.3 \mathrm{~mol} \%$.

The type strain, SL213 ${ }^{\mathrm{T}}\left(=\right.$ KCTC $\left.13078^{\mathrm{T}}=\mathrm{JCM} 14638^{\mathrm{T}}\right)$, was isolated from vineyard soil in Daejeon, Korea. Strain SL1213, isolated from the same source, is a second strain of the species.

\section{Acknowledgements}

We are grateful to Dr Jean P. Euzéby (Society for Systematic and Veterinary Bacteriology, France) for his advice on nomenclatural queries. This work was supported by grants KHS4120711 and BDM0200726 from the Ministry of Science and Technology (MOST), and the KRIBB Research Initiative Program, Republic of Korea. We are indebted to the Korea Basic Science Institute (KBSI), Republic of Korea, for the transmission electron microscope.

\section{References}

Albert, R. A., Archambault, J., Rosselló-Mora, R., Tindall, B. J. \& Matheny, M. (2005). Bacillus acidicola sp. nov., a novel mesophilic, acidophilic species isolated from acidic Sphagnum peat bogs in Wisconsin. Int J Syst Evol Microbiol 55, 2125-2130.

Alkan, H., Baysal, Z., Uyar, F. \& Dogru, M. (2007). Production of lipase by a newly isolated Bacillus coagulans under solid-state fermentation using melon wastes. Appl Biochem Biotechnol 136, 183-192.

Bae, S. S., Lee, J. H. \& Kim, S. J. (2005). Bacillus alveayuensis sp. nov., a thermophilic bacterium isolated from deep-sea sediments of the Ayu Trough. Int J Syst Evol Microbiol 55, 1211-1215.

Becker, M. E. \& Pederson, C. S. (1950). The physiological characters of Bacillus coagulans (Bacillus thermoacidurans). J Bacteriol 59, 717725.

Chang, Y. H., Kim, J. K., Kim, H. J., Kim, W. Y., Kim, Y. B. \& Park, Y. H. (2001). Selection of a potential probiotic Lactobacillus strain and subsequent in vivo studies. Antonie van Leeuwenhoek 80, 193-199.

Chang, Y. H., Han, J., Chun, J. S., Lee, K. C., Rhee, M. S., Kim, Y. B. \& Bae, K. S. (2002). Comamonas koreensis sp. nov., a non-motile species from wetland in Woopo, Korea. Int J Syst Evol Microbiol 52, 377-381.

Cohn, F. (1872). Untersuchungen ber Bakterien. Beitr Biol Pflanz 1, 127-244 (in German).

De Clerck, E., Rodriguez-Diaz, M., Forsyth, G., Lebbe, L., Logan, N. A. \& De Vos, P. (2004). Polyphasic characterization of Bacillus coagulans strains, illustrating heterogeneity within this species, and emended description of the species. Syst Appl Microbiol 27, 50-60.

Ezaki, T., Hashimoto, Y. \& Yabuuchi, E. (1989). Fluorometric deoxyribonucleic acid-deoxyribonucleic acid hybridization in microdilution wells as an alternative to membrane filter hybridization in which radioisotopes are used to determine genetic relatedness among bacterial strains. Int J Syst Bacteriol 39, 224-229.

Felsenstein, J. (1985). Confidence limits on phylogenies: an approach using the bootstrap. Evolution 39, 783-791.

Felsenstein, J. (1993). PHYLIP (phylogeny inference package), version 3.5c. Distributed by the author. Department of Genome Sciences, University of Washington, Seattle, USA.

Fitch, W. M. (1971). Toward defining the course of evolution: minimum change for a specific tree topology. Syst Zool 20, 406-416.
Fitch, W. M. \& Margoliash, E. (1967). Construction of phylogenetic trees. Science 155, 279-284.

Gatson, J. W., Benz, B. F., Chandrasekaran, C., Satomi, M., Venkateswaran, K. \& Hart, M. E. (2006). Bacillus tequilensis sp. nov., isolated from a 2000-year-old Mexican shaft-tomb, is closely related to Bacillus subtilis. Int J Syst Evol Microbiol 56, 1475-1484.

Gibson, T. \& Gordon, R. E. (1974). Genus I. Bacillus Cohn 1872, 174. In Bergey's Manual of Determinative Bacteriology, 8th edn, pp. 529550. Edited by R. E. Buchanan \& N. E. Gibbons. Baltimore: Williams \& Wilkins.

Gugliandolo, C., Maugeri, T. L., Caccamo, D. \& Stackebrandt, E. (2003). Bacillus aeolius sp. nov. a novel thermophilic, halophilic marine Bacillus species from Eolian Islands (Italy). Syst Appl Microbiol 26, 172-176.

Hammer, B. W. (1915). Bacteriological studies on the coagulation of evaporated milk. Iowa Agric Exp Stn Res Bull 19, 119-131.

Heyrman, J., Rodríguez-Díaz, M., Devos, J., Felske, A., Logan, N. A. \& De Vos, P. (2005). Bacillus arenosi sp. nov., Bacillus arvi sp. nov. and Bacillus humi sp. nov., isolated from soil. Int J Syst Evol Microbiol 55, 111-117.

Horowitz-Wlassowa, L. M. \& Nowotelnow, N. W. (1932). Über eine sporogenes Milchsaurebakterienart, Lactobacillus sporogenes n. sp. Zentralbl Bakteriol II Abt 87, 331 (in German).

Jukes, T. H. \& Cantor, C. R. (1969). Evolution of protein molecules. In Mammalian Protein Metabolism, vol. 3, pp. 21-132. Edited by H. N. Munro. New York: Academic Press.

Kotay, S. M. \& Das, D. (2007). Microbial hydrogen production with Bacillus coagulans IIT-BT S1 isolated from anaerobic sewage sludge. Bioresour Technol 98, 1183-1190.

Logan, N. A., Lebbe, L., Verhelst, A., Goris, J., Forsyth, G., RodriguezDiaz, M., Heyndrickx, M. \& De Vos, P. (2002). Bacillus luciferensis sp. nov., from volcanic soil on Candlemas Island, South Sandwich archipelago. Int J Syst Evol Microbiol 52, 1985-1989.

Palmisano, M. M., Nakamura, L. K., Duncan, K. E., Istock, C. A. \& Cohan, F. M. (2001). Bacillus sonorensis sp. nov., a close relative of Bacillus licheniformis, isolated from soil in the Sonoran Desert, Arizona. Int J Syst Evol Microbiol 51, 1671-1679.

Patel, M. A., Ou, M. S., Harbrucker, R., Aldrich, H. C., Buszko, M. L., Ingram, L. O. \& Shanmugam, K. T. (2006). Isolation and characterization of acid-tolerant, thermophilic bacteria for effective fermentation of biomass-derived sugars to lactic acid. Appl Environ Microbiol 72, 3228-3235.

Rhuland, L. E., Work, E., Denman, R. F. \& Hoare, D. S. (1955). The behavior of the isomers of $\alpha, \varepsilon$-diaminopimelic acid on paper chromatograms. J Am Chem Soc 77, 4844-4846.

Saitou, N. \& Nei, M. (1987). The neighbor-joining method: a new method for reconstructing phylogenetic trees. Mol Biol Evol 4, 406-425.

Schleifer, K. H. \& Kandler, O. (1972). Peptidoglycan types of bacterial cell walls and their taxonomic implications. Bacteriol Rev 36, 407-477.

Shida, O., Takagi, H., Kadowaki, K., Nakamura, L. K. \& Komagata, K. (1997). Transfer of Bacillus alginolyticus, Bacillus chondroitinus, Bacillus curdlanolyticus, Bacillus glucanolyticus, Bacillus kobensis, and Bacillus thiaminolyticus to the genus Paenibacillus and emended description of the genus. Int J Syst Bacteriol 47, 289-298.

Shivaji, S., Chaturvedi, P., Suresh, K., Reddy, G. S., Dutt, C. B., Wainwright, M., Narlikar, J. V. \& Bhargava, P. M. (2006). Bacillus aerius sp. nov., Bacillus aerophilus sp. nov., Bacillus stratosphericus sp. nov. and Bacillus altitudinis sp. nov., isolated from cryogenic tubes used for collecting air samples from high altitudes. Int J Syst Evol Microbiol 56, 1465-1473. 
Stackebrandt, E. \& Goebel, B. M. (1994). Taxonomic note: a place for DNA-DNA reassociation and $16 \mathrm{~S}$ rRNA sequence analysis in the present species definition in bacteriology. Int J Syst Bacteriol 44, 846849.

Staneck, J. L. \& Roberts, G. D. (1974). Simplified approach to identification of aerobic actinomycetes by thin layer chromatography. Appl Microbiol 28, 226-231.

Tamaoka, J. \& Komagata, K. (1984). Determination of DNA base composition by reversed-phase high-performance liquid chromatography. FEMS Microbiol Lett 25, 125-128.

Wayne, L. G., Brenner, D. J., Colwell, R. R., Grimont, P. A. D., Kandler, O., Krichevsky, M. I., Moore, L. H., Moore, W. E. C., Murray, R. G. E. \& other authors (1987). International Committee on Systematic Bacteriology. Report of the ad hoc committee on reconciliation of approaches to bacterial systematics. Int J Syst Bacteriol 37, 463-464.

Yanagida, F., Suzuki, K., Kozaki, M. \& Komagata, K. (1997). Proposal of Sporolactobacillus nakayamae subsp. nakayamae sp. nov., subsp. nov., Sporolactobacillus nakayamae subsp. racemicus subsp. nov., Sporolactobacillus terrae sp. nov., Sporolactobacillus kofuensis sp. nov., and Sporolactobacillus lactosus sp. nov. Int J Syst Bacteriol 47, 499-504.

Yoon, J. H., Kim, I. G., Kang, K. H., Oh, T. K. \& Park, Y. H. (2003). Bacillus marisflavi sp. nov. and Bacillus aquimaris sp. nov., isolated from sea water of a tidal flat of the Yellow Sea in Korea. Int J Syst Evol Microbiol 53, 1297-1303. 